\section{B A Institute of \\ YK Business Administration \\ 六下 \\ Karachi \\ Leadership and Ideas for Tomorrow}

Business Review

Volume 12 Issue 1 January-June 2017

$1-1-2017$

\title{
A retrospective insight into Pakistan's exchange rate regimes and their impact on the economy
}

\author{
Lalarukh Ejaz \\ Institute of Business Administration, Karachi, Pakistan \\ Madeeha Akhtar \\ Institute of Business Administration, Karachi, Pakistan
}

Follow this and additional works at: https://ir.iba.edu.pk/businessreview

Part of the Finance Commons, and the Macroeconomics Commons

\section{(c) ()}

This work is licensed under a Creative Commons Attribution 4.0 International License.

\section{Recommended Citation}

Ejaz, L., \& Akhtar. M. (2017). A retrospective insight into Pakistan's exchange rate regimes and their impact on the economy. Business Review, 12(1), 89-97. Retrieved from https://doi.org/10.54784/ 1990-6587.1051

This article is brought to you by iRepository for open access under the Creative Commons Attribution 4.0 License and is available at https://ir.iba.edu.pk/businessreview/vol12/iss1/6. For more information, please contact irepository@iba.edu.pk. 


\title{
Case: A retrospective insight into Pakistan's exchange rate regimes and their impact on the economy
}

\author{
Lalarukh Ejaz • Madeeha Akhtar
}

\begin{abstract}
Nuclear tests carried out by Pakistan in May 1998 had a distinctive impact on the evolution of the exchange rate. This case describes what happened to the exchange rate before and after the nuclear tests and focuses on the overall impact of Pakistan's transition from a hostile relationship with the US in the post-Cold War era to becoming an ally of the US in the war on terror. This case can be used to study the concepts of real and nominal exchange rates, the linkage between exchange rate policy and external balance, how exchange rate can be used as a tool to control the economy and the impact on the economic situation of sustaining a particular exchange rate.
\end{abstract}

Keywords Exchange rate · Economy · Growth · Inflation · Current account · Remittances

\section{Introduction}

The rumour spread like wild fire in Jodia Bazaar. It was around noon on a hot day in October 2008. Hasan had stopped at a newspaper stand when he heard some people from his business community talk of it in hushed tones, as if, saying it aloud would make it come true. It would have been disastrous for all of them. "There is talk of lockers getting seized, Hasan. They might come after our bank accounts too: especially the foreign accounts. I suggest take all your money out as soon as possible" his supplier who was waiting for Hasan to open the shop cautioned when Hasan unlocked the shutters. Hasan became grim instantaneously. "But my payments-Is this news confirmed?" he asked. "It's just a rumour at this stage; no government official has appeared on TV to confirm it. But Hasan bhai you must act soon," his vendor replied.

Lalarukh Ejaz

Institute of Business Administration, University Road, Karachi Pakistan

E-mail: Lejaz@iba.edu.pk

Madeeha Akhtar

Institute of Business Administration, University Road, Karachi Pakistan

(C)Ejaz,L. and Akhtar,M. (2017) 
Hasan belonged to the group of small businessmen who were slowly making inroads in the large market of existing players. He had recently begun exporting rice and other agricultural products to markets in the Middle East. His main exports went to Dubai and Oman.

His thoughts went back to the bittersweet memories ten and a half years ago when he was still a little kid. In the 1990s, Pakistan saw a shaky succession of governments. Benazir Bhutto had been prime minister twice and deposed twice. In early 1997 Nawaz Sharif was serving a second term as Prime Minister in the newly elected government. During this time a two pronged strategy had been adopted to revive the agricultural and industrial sector. In order to boost production of wheat, rice, sugar and other crops, both the procurement quantities and the minimum prices of these commodities were greatly increased. Taxes across all categories had been significantly reduced to stimulate the manufacturing sector. Growth rates of manufacturing and agriculture improved considerably in response to these policy measures in 1997-98 but the growth trajectory could not be maintained afterwards. Figure 1 below shows the GDP growth rate of Pakistan from 1995-2004. Although these measures boosted income and

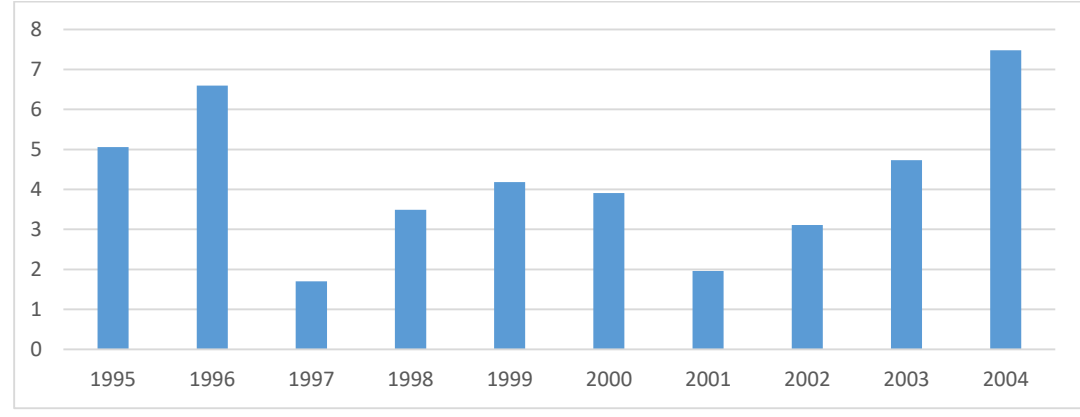

Fig. 1: Pakistan GDP growth rate from 1995-2004 Source: Pakistan Bureau of Statistics

employment in the short run they resulted in the misallocation of resources and significantly increased the proportion of non-performing loans (NPL) for banks already under distress and subject to political patronage.

\section{The nuclear tests and its aftermath}

Fear and panic gripped Hasan and he felt a chill run down his spine as all around him the shopkeepers in the market attempted to analyse again and again whether and how the government would freeze their accounts. His mind was a boggle as he tried to track his upcoming receipts and payments and the balances in his two business accounts. Subconsciously he tried to compare the situation in 1998 with the current scenario to ascertain the likelihood of the rumours coming true.

It had only been a year into Nawaz Sharif's government and in a bold move 
Pakistan had tested the nuclear bombs successfully on 28th May 1998 in retaliation against India's nuclear tests 11 days earlier. The memories vividly flashed in his mind. It had been an occasion for celebration in Pakistan. Every one had been all praises for the Prime Minister for taking this decision to safeguard the sovereignty of the country. But this spell of happiness was rather short lived as the international community was quick to condemn Pakistan's actions. It was labelled as dangerous development and the world feared an arms race among the two arch rivals, India and Pakistan. Consequently United States and other western countries imposed sanctions chiefly on Rennack (2003).

- all types of foreign aid with the exception of food and humanitarian assistance;

- sale of defense related products, design and construction services, licenses for exporting U.S. Munitions List (USML) items;

- external military funding;

- U.S. government-backed credit or financial support;

U.S. also opposed loans or assistance from any international financial institutions, prohibited exports of sensitive goods and technology and declined credit or other Export-Import Bank assistance for exports. Loans from international financial institutions, such as the IMF and World Bank were also put on hold Malik (2011).

As of April 1998, IMF had yet to disburse $\$ 1.2$ billion to Pakistan. At that time the country's foreign exchange reserves stood at $\$ 1.4$ billion which was sufficient only for about 90 days of imports. The nuclear blasts created a situation of a speculative attack on the currency. A speculative attack can be defined as a large scale selling of the country's currency by both local and foreign investors. The low levels of reserves further exacerbated this crisis. When the reserves are higher the ability of the foreign exchange dealers to speculate is limited as they believe that the government has the funds to stabilize the exchange rates. For Pakistan this led to an exodus of foreign investments from the country. Pakistani rupee depreciated $30 \%$ against the dollar. Furthermore the prophecies of withdrawal of IMF support triggered a collapse of market confidence, which affected the capital flows, the exchange rate, and the GDP growth.

Despite expectation to the contrary, the Pakistani economy stood resilient in the face of the sanctions imposed consequent to the nuclear blasts in 1998. There was a general prediction that the impact on India would be comparatively less intense as it possessed huge foreign exchange reserves but that Pakistan's economy would bear the greater brunt in view of the poor reserves position even before the sanctions. It was dreaded that the exchange rate would fall and prices of essential commodities would spiral rapidly. However this did not happen and the economy held up reasonably well in the short duration between the imposition of sanctions and the receipt of balance of payments support from the IMF Pasha (2000). 


\section{Pakistan's economy before the nuclear tests}

Pakistan had maintained a de facto peg for much of the time since the early 1990s (see figure 2). With the exception of the period following the balance of payments crisis and the freeze of foreign currency accounts in mid-1998, the value of the rupee against the dollar has fluctuated very little, whether seen from a 2-year or 5-year window. This said, the parity of the rupee has been

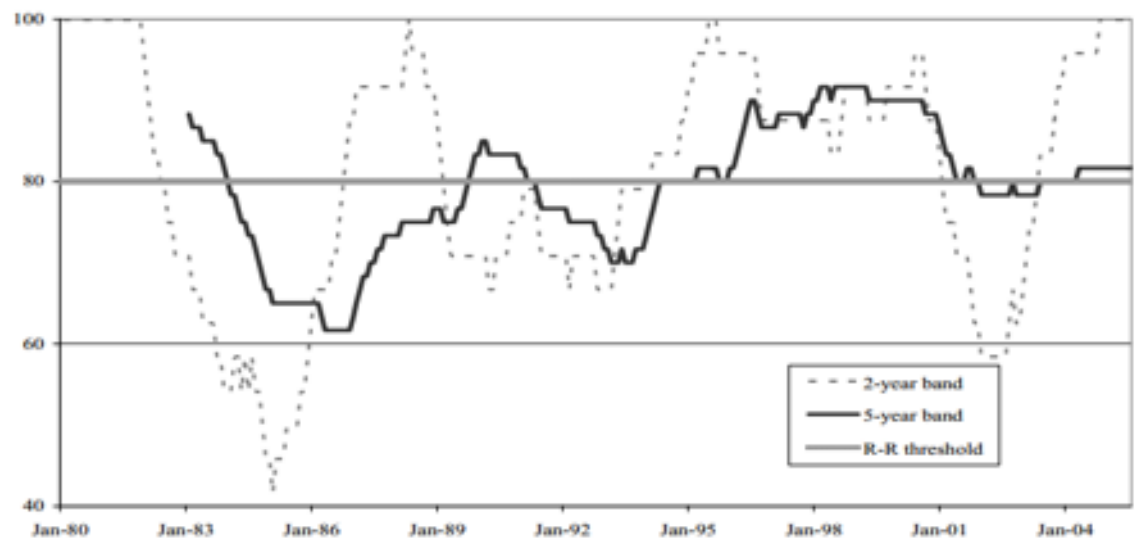

Fig. 2: Pakistan-Degree of flexibility against the US Dollar-Proportion of monthly exchange rate changes less than $+/-1$ percent

Source:http:citeseerx.ist.psu.edu/viewdoc/download?doi=10.1.1.491.5582\&rep=rep1\&type=pdf

adjusted, sometimes in large steps. But these adjustments, especially the larger ones, were sufficiently infrequent that the exchange rate regime of the rupee may be considered a de facto peg to the dollar Husain et al (2006).

\subsection{Fixed exchange rate (1947-1971)}

After independence in 1947 Pakistan adopted a fixed exchange rate regime. The rupee was linked to the sterling and in 1949 the sterling was devalued followed by the subsequent devaluation of the Indian rupee. The Pakistani government also faced pressure to devalue the currency but it stood up to the pressure and did not devalue the Pakistani rupee as the export earnings were rather limited and devaluation would make the imports of machinery and capital equipment required for the newly industrializing economy more expensive.

In August 1955 however, Pakistan had to devalue its currency subsequent to the Korean War boom as the country fell into a recession along with other world economies and faced a severe shortage of foreign exchange. As the influence of 
the US economy increased in the worldly economic matters Pakistan switched its peg from sterling to the dollar on 17th September 1971.

3.2 Fixed exchange rate regime during the Bhutto era (1971-1977)

In February 1973, the US Dollar was devalued by 10 percent which led to subsequent revaluation of Pakistani Rupee by 10 per cent to Rs 9.90 per dollar and it remained fixed at this level until the decision to adopt the managed float in 1982. During the fixed exchange rate regime from 1973-1982, actual real effective exchange rate moved in tandem with the price differential and the movement of US Dollar vis--vis major currencies. The Rupee regained competitiveness in real terms during 1976-1979 because of the continued lower inflation differential and US Dollar depreciation vis--vis major currencies. During early 1980s, real effective exchange rate appreciated substantially due to appreciation of the US Dollar against major currencies and higher domestic inflation as compared to trading partners.

\subsection{Managed float (1982-1997)}

The decision to adopt the managed float was made in view of the international trend towards deregulation of economies and exchange rates. The country was also experiencing rampant inflation, large fiscal deficit and decline in remittances. In lieu of all these problems the currency was overvalued and therefore to counter these challenges the currency was delinked with the dollar and linked to the currencies of 16 major trading partners. Pakistan adopted the managed floating exchange rate system on January 8, 1982. This adjustment enabled the country to register a growth rate of 26.8 percent per year during this time period.

The period thereafter was characterized with more frequent and small adjustments in Rupee against US Dollar, keeping in view the relative changes in exchange rates and prices of country's major trading partners/competitors as well as various macroeconomic indicators of Pakistan. With the transformation of the economy from a semi-closed to a more open or market-oriented economy in the beginning of 1990s, exchange rate saw a much larger devaluation in nominal terms which was partially offset by a higher level of inflation in Pakistan as compared to its trading partners.

Some measures were introduced to reform the exchange and payments system. The purpose was to attract funds held by citizens abroad. These included removal of restrictions on holding foreign currency and on foreign payments, liberalization of rules regarding private sector foreign borrowing and residents were allowed to open foreign currency accounts. As a part of the trade liberalization program in 1994 the central bank implemented full convertibility for current account transactions and partial convertibility for capital account transactions. Complete foreign equity participation was allowed and there were no restrictions on repatriation of profits, capital and royalty. 


\section{Economic measures to soften the blow of the sanctions post 1998}

The imposition of economic sanctions following the nuclear tests in May 1998 created a crisis-like situation. As capital began to take flight, a huge forex liability emerged; therefore withdrawal in hard currency from foreign currency accounts, certificates of investment issued by non-bank financial institutions and encashment of foreign currency instruments were suspended. SBP introduced a number of measures including the implementation of a two-tier exchange rate system among others from July 1998 to steer the economy from the crisis. The government adopted the system of multiple exchange rate which was made up of an official exchange rate pegged to the dollar, a floating interbank rate and a composite rate pegged combining the FIBR and the official rate.

Furthermore to compensate for the crisis and the loss of private sector confidence, the government allowed conversion of dollars into rupees at the prevailing exchange rate coupled with further incentives e.g. withdrawal of tax and zakat deduction to encourage their conversion into the rupees. Holders of FCAs were also offered Special US Dollar Bonds against the foreign exchange in their accounts. These bonds were later made more attractive by reducing the minimum maturity period from 5 to 3 years and raising the maximum rate of return from LIBOR +2 to LIBOR +4 per cent. Soon under a new FCA scheme surrender requirement for banks and forward cover facility from SBP were removed. However, a year later financial institutions were directed to keep such funds with the SBP.

Hasan was jerked out of his thoughts by a customer. He wanted to concentrate on making the deal with his client but his mind wandered elsewhere. Whatever little saving he had was invested in his business accounts. Part of him wanted to believe that the current situation was very different from that of 1998. Surely the financial system of the country must have evolved in the past ten years and the government would be having other measures to control the flight of capital rather than freezing the bank accounts - Hasan mumbled to himself. With all the conversation taking place Hasan could not focus on his work at all. He had to take deliveries from a supplier but it seemed that this was the only issue that everyone could talk about.

\subsection{The new exchange rate regime (1998-2000)}

There was a new mechanism in place to regulate the exchange rate regime in July 1998. It consisted of an official exchange rate and floating inter-bank exchange rate (FIBR). While the official exchange rate was fixed by SBP, FIBR was determined in the inter-bank market. Slowly and gradually the share of FIBR in the composite exchange rate increased and in May 1999, the market-based unified exchange rate system was adopted and in July 2000 the Rupee was put to a complete float. This was a major achievement in the area of exchange rate management. The multiple exchange rate system was done away with and the new system was also known as the dirty floating exchange rate. The exchange rate was maintained within a narrow margin till July 2000. 


\subsection{Restriction on approved dealers}

The requirement that the Approved Dealers (AD) had to surrender all foreign exchange receipts to SBP was abolished but with a view to prevent unchecked capital outflows, the powers of ADs were restricted. In time, however, with improved economic conditions, most of these restrictions were relaxed. Other than restrictions on ADs, the facilities to import through contracts/purchase orders/proforma invoice/ indent were abolished and minimum cash margin requirements were imposed to curtail imports. However, both of these restrictions were removed later with improvement in forex reserve position of the country.

The year 1998-99 ended with positive fundamentals. The inflation rate fell 6 percent while the currency devaluation was not greater than 16 percent. The GDP growth was registered at 3 percent and there was no fall in real per capita income. This was realised by a combination of favourable underlying factors and strong policy measures. Among the former were a bumper wheat crop in the prior year, sharp fall in import prices, particularly of petroleum products, the thrust of the informal economy and support from friendly countries. The strong policy moves to manage the disaster situation included the freezing of foreign currency accounts, imposition of stringent capital controls, introduction of import margin requirements, changeover to a dual exchange rate regime with the lower official rate applicable on essential imports, a large surge in the tax on petrol, steep cut backs in public expenditure, postponement of public sector imports and non-repayment of debt (except to multilateral preferred creditors) Pasha (2000). However, these policy actions did lead to a loss of confidence among both domestic and foreign participants.

\section{Musharraf era (2001-2008) and 9/11}

Close ties with Afghanistan's Taliban government thrust Pakistan into a difficult position following the September 11 terrorist attacks. Prior to these attacks US looked upon Pakistan unfavourably as a failed state that was promoting and supporting terrorism. Subsequent to the attacks, President Musharraf realigned the policy of the country changing direction from a pro Taliban foreign policy to an ally of the US in the war on terrorism. The decision was taken in the best interest of the country to protect national sovereignty and assets and to provide support to the sinking economy. In return, President Bush ended the sanctions (instituted after Pakistan's testing of nuclear weapons in 1998), rescheduled its debt, and helped to bolster the legitimacy of the rule of Pervez Musharraf, who appointed himself president in 2001.

From 1998 to 2001 the economic situation of the country was highly unstable. The rating of the country had been downgraded to default level by the international credit rating agencies, foreign exchange reserves were depleting and there was complete loss of investor confidence. It was with this state of the economy that the country joined the international coalition against terrorism. The substantial surge in workers' remittances into the interbank market following the international crackdown on informal channels after September 11 


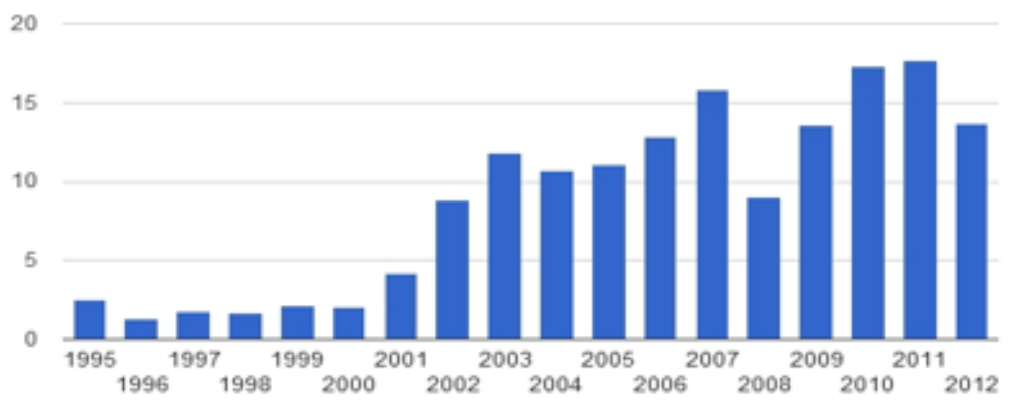

Fig. 3: Pakistan Foreign Exchange Reserves 1995-2012 - The surge in forex reserves post 2001 due to increased remittances

Source: State Bank of Pakistan

incident reversed the downward trend in exchange rate. The foreign exchange reserves started to build up after 2001 as can be seen in figure 3 above. The excess liquidity in the foreign exchange market, following the post-September 11 surge in workers' remittance into the formal banking channel, induced SBP to purchase US $\$ 8.2$ billion from October 2001- March 2004 to preserve the competitiveness of exports from an abrupt exchange rate appreciation. The increased demand of foreign exchange from importers dried down the excess liquidity, which prompted SBP to scale down its purchases from the interbank market and provide market support by financing the lumpy oil payments. Interestingly, rupee, in real terms, continued to maintain its compositeness due to the fact that the basket of currencies appreciated against the dollar more than the rupee and the relatively higher inflation compared to trading partners Hyder and Mahboob (2006).

From 20th July 2000 the country had completely shifted to the flexible exchange rate system. The central bank's influence had been limited to easing out the fluctuations in the exchange rate and it did so using the US dollar. Foreign exchange restrictions and controls were minimal. Current account transactions were now unrestricted except for occasionally imposed limits on advance payments for some imports. Foreign investors could freely bring in and take out their capital, profits, dividends, royalties, etc. Pakistan's exchange rate regime was thus, a de facto conventional peg to the US dollar within a narrow band.

\section{Conclusion}

Hasan sipped at his tea and tried to calm himself. The panic that grew within him was overwhelming. He tried to get in touch with his friends and colleagues to get another opinion. The response was the same that the banking system was facing a liquidity crisis and was on the verge of default. People were hurrying to banks to withdraw their money and a large number of people were drawing out cash from ATMs. The level of anxiety was high and it further skyrocketed 
as ATMs ran out of cash and banks closed down their branches before the usual closing time. What could he do? In a surge of terror Hasan picked up his cell phone and dialled his bank manager. Relief poured over him when he heard the manager's unruffled voice at the other end labelling the rumours of the dollar freeze as baseless and rubbish.

It was the public confidence in the banking system that had crashed. The SBP spokesperson on national media soon revealed that the foreign currency accounts enjoyed protection under the Foreign Currency Accounts Ordinance 2001. The government was not considering such a step and the rumours had originated in the stock market where the imposition of the floor had driven away investors and had been fuelled by other factors such as diminishing forex reserves and terrorist attacks across the country.

Although the rumours had been quelled by government officials in various media, the road ahead was still uncertain for businessmen like Hasan. With the economic environment marked by crisis at regular intervals it was extremely difficult to pacify international clients and suppliers who were reluctant to have anything to do with businesses from Pakistan. The instability of the political and the economic environment was exerting its toll on business activities. Where had the government gone so terribly wrong? What were the factors responsible for the destabilization of the economy to the extent that carrying out business had become such a problematic task. These were the questions that cartwheeled in Hasan's mind as he went about his routine activities.

\section{References}

Husain AM, et al (2006) Choosing the right exchange rate regime for pakistan. State Bank of Pakistan Research Bulletin 2(1):92-111

Hyder Z, Mahboob A (2006) Equilibrium real effective exchange rate and exchange rate misalignment in pakistan. SBP Research Bulletin 2(1)

Malik N (2011) Economic sanctions imposed on pakistan and their impact (1979-2001) singapore: Lee kuan yew school of public policy, national university singapore.

Pasha HA (2000) Elements of Good Economic Governance. Social Policy and Development Centre

Rennack DE (2003) India and pakistan: Us economic sanctions. Congressional Research Service, Library of Congress 